\author{
WIESŁAWA GIERAŃCZYK \\ Uniwersytet im. Mikołaja Kopernika, Toruń
}

\title{
Rola przedsiębiorstw w polskiej gospodarce w okresie transformacji ustrojowej
}

Ogół radykalnych zmian w systemie funkcjonowania polskiej gospodarki po 1989 określany jest mianem transformacji systemowej. Jako główną zasadę przeobrażeń w Polsce przyjęto, że zmiany powinny zmierzać do ukształtowania się gospodarki rynkowej, w której szczególną rolę pełnią przedsiębiorstwa. Pod względem ekonomicznym i prawnym przedsiębiorstwo to wyodrębniona jednostka gospodarcza, prowadząca działalność w celu osiągnięcia korzyści ekonomicznych, tj. zysku i wzrostu wartości rynkowej firmy.

Współcześnie obserwuje się dwie przeciwstawne tendencje w zakresie kształtowania się wielkości przedsiębiorstw. Znanym i dość powszechnym zjawiskiem jest, zapoczątkowany jeszcze w XIX wieku, proces koncentracji produkcji i kapitału. Firmy starają się zwiększyć swoją wielkość, aby zdobyć większy udział w rynku, zmniejszyć ryzyko działalności przez rozszerzenie asortymentu produkcji, powiększyć zakres swej działalności, wynikający z łączenia różnych rodzajów tejże działalności, pozyskać korzyści wynikające z posiadania doświadczenia, sieci dystrybucyjnej i dostatecznych środków na prace badawczo-rozwojowe.

Funkcjonalna integracja rozproszonych po świecie jednostek organizacyjnych najpełniej realizowana jest przez największe przedsiębiorstwa, które sukcesywnie i konsekwentnie rozszerzają zasięg swego działania. Przedsiębiorstwa powiększają swój potencjał, m.in. poprzez podejmowanie wspólnych inwestycji, dobrowolne łączenie się w coraz większe organizmy gospodarcze, fuzje i przejęcia lub też poprzez wchłanianie mniejszych przedsiębiorstw. Integracja ekonomiczna może mieć różny przebieg, skalę i zasięg. O integracji poziomej mówi się, gdy w skład organizacji integracyjnej wchodzą przedsiębiorstwa wytwarzające takie same lub podobne produkty. Integracja pionowa zachodzi natomiast, gdy łączą się przedsiębiorstwa różnych gałęzi i branż, uczestniczące w kolejnych fazach procesu produkcji dobra finalnego. Gdy między przedsiębiorstwami zachodzą relacje pionowe i poziome, tworzą się konglomeraty.

Bardzo często określona grupa przedsiębiorców chce wspólnie zrealizować pewne przedsięwzięcie gospodarcze, na przykład wspólnie przystąpić do przetargu na wykonanie kompleksowego zadania (budowa odcinka autostrady, produkcja podzespołu do samochodu itp.). W tym przypadku bardzo użyteczna jest formuła konsorcjum, którego jurystyczna natura wyraża się we wzajemnym zobowiązaniu uczestników do wspólnego dążenia do osiągnięcia wytyczonego celu gospodarczego poprzez podejmowanie określonych działań. Konsorcjum nie uzyskuje osobowości prawnej i nie podlega obowiązkowi wpisu do rejestru. 
Umowa konsorcjum jest bardzo przydatną formą prawną i organizacyjną dla tych przedsiębiorców, którzy chcą pomóc sobie nawzajem nie angażując się jednocześnie znaczącym majątkiem. Jej zasadnicza zaletą, bardzo cenną w określonych warunkach, jest fakt, że nie wymaga rejestracji, a formalności związane z jej powołaniem i rozwiązaniem ograniczone są do niezbędnego minimum. Może być ona przydatna do tworzenia lub wspomagania różnych sieciowych rozwiązań grup kooperacyjnych, powstających we współczesnej gospodarce rynkowej, podobnie jak holding.

Pojęcie holding nie występuje w polskim prawodawstwie. W praktyce życia gospodarczego przyjęto określać tym pojęciem związki pomiędzy podmiotami gospodarczymi, polegające na tym, że:

- wchodzące w nie podmioty są spółkami kapitałowymi (posiadają osobowość prawna);

- jedna ze spółek posiada udziały (akcje) innych spółek;

- powstaje zależność pomiędzy podmiotami, ponieważ posiadane udziały (akcje) zapewniają spółce dominującej możliwości wpływu na działania pozostałych.

Przedsiębiorstwa łączą się, ponieważ dysponując większą siłą mogą dyktować warunki innym uczestnikom rynku. Jeżeli jedno przedsiębiorstwo kontroluje rynek, mówi się o monopolu. Monopol to rynek, na którym występuje jedyny producent (sprzedawca) dobra lub usługi. Brak konkurencji pozwala monopoliście na ograniczenie podaży, podniesienie ceny i osiągniecie zysku nadzwyczajnego. Państwo może również występować i działać jako monopolista, ustalając wyższe ceny i pobierając wyższe opłaty. Monopole regulowane przez rząd czy monopole prywatne stanowią poważną barierę w rozwijaniu zdrowej konkurencji. Monopol występuje zazwyczaj w dziedzinach, w których warunki produkcji nie pozwalają na poważne jej rozszerzenie ze względu na rzadkość występowania danego czynnika produkcji (specjalne warunki glebowo-klimatyczne, rzadkie bogactwa naturalne), a zapotrzebowanie na dany produkt jest duże. Taka sytuacja pozwala producentowi na ustalenie wysokiej ceny, która nawet kilkakrotnie może przewyższać rzeczywiste koszty produkcji.

Sytuacja monopolu pojawia się również na skutek porozumień między przedsiębiorstwami. Formą monopolu jest koncern. Koncern to grupa przedsiębiorstw należących do tego samego właściciela, mających jednak odrębną osobowość prawną. Koncern posiada wspólny zarząd, jego struktura polega na istnieniu przedsiębiorstwa dominującego oraz grupy przedsiębiorstw zależnych, poddanych jednolitemu kierownictwu, jeśli idzie o rozstrzyganie najważniejszych kwestii, niezależnych jednak często w swej bieżącej, operatywnej działalności, nie tracących swej odrębności organizacyjnej i prawnej. Do jego utworzenia dochodzi przez fuzję lub przez wykup kontrolnego pakietu udziałów, ale również przez zgodę na korzystanie przez przedsiębiorstwo dominujące z patentów, licencji itp. innych członków koncernu. Najczęściej jest to związek spółek. Koncern może mieć charakter struktury pionowej, obejmującej przedsiębiorstwa działające w kolejnych fazach jednego, dużego procesu technologicznego, bądź poziomej, obejmującej jednostki wykorzystujące te same technologie, wspólną bazę surowcową itp. Może mieć również strukturę bardziej luźną, zbliżoną do konglomeratu. Głównym celem koncernu jest zlikwidowanie konkurencji między przedsiębiorstwami oraz utworzenie wspólnoty kapitałowej wzmacniającej podstawy funkcjonowania, co daje możliwości rozszerzenia zakresu działalności gospodarczej, opanowania rynków zbytu oraz poprawy efektywności gospodarowania. 
Tabela 1. Koncentracja produkcji i kapitału w największych przedsiębiorstwach w Polsce w 2002 r.

\begin{tabular}{|l|c|c|c|}
\hline \multirow{2}{*}{$\begin{array}{c}10 \\
\text { 10 największych przedsię- } \\
\text { biorstw pod względem: }\end{array}$} & \multicolumn{3}{|c|}{ Udział w stosunku do ogółu przedsiębiorstw } \\
\cline { 2 - 4 } & Zatrudnienie & Zysk netto* & Przychody \\
\hline zatrudnienia & 35,2 & 14,1 & 10,8 \\
\hline zysków netto & 34,6 & 11,2 & 16,5 \\
\hline przychodów & 21,1 & 26,9 & 21,1 \\
\hline
\end{tabular}

* tylko zysk netto, bez uwzględnienia strat

Źródło: opracowanie własne na podstawie: „Pięćsetka Polityki” [w:] http://polityka.onet.pl/rank500_2003/ sortLp15.html

W 2002 r. spośród przedsiębiorstw, które uczestniczyły w rankingu tygodnika „Polityka", największe pod względem przychodów były polskie i zagraniczne koncerny oraz przedsiębiorstwa państwowe. W analizie informacji zawartych $\mathrm{w}$ tym rankingu zwraca uwage fakt, iż liderami pod względem zatrudnienia były przedsiębiorstwa polskie (przedsiębiorstwa państwowe i przedsiębiorstwa z udziałem Skarbu Państwa) działające w zmonopolizowanych sektorach gospodarki (usługi pocztowe, przewozy kolejowe, górnictwo węgla kamiennego). Spośród 10 największych pod względem zatrudnienia przedsiębiorstw, które zatrudniały łącznie 35,2\% ogółu zatrudnionych w stosunku do ogółu analizowanych, zyski osiągnęło osiem firm. Stanowiły one 14,1\% zysków badanej grupy. Silna koncentracja dostrzegalna była także pod względem uzyskanego zysku netto. Spośród 500 analizowanych przedsiębiorstw 10 największych pod względem wysokości wypracowanego zysku netto dysponowało 1/3 ogółu zysków wypracowanych przez wszystkie przedsiębiorstwa. Przy czym przedsiębiorstwa te skupiały $11,2 \%$ potencjału zatrudnienia i 16,5\% ogółu uzyskanych przychodów. Najbardziej zyskownymi w 2002 r. przedsiębiorstwami były firmy działające w branży telekomunikacyjnej (Telekomunikacja Polska S.A., Polkomtel S.A., Polska Telefonia Cyfrowa S.A.), produkcji i dystrybucji paliw (PKN Orlen S.A., PGNiG S.A.) oraz pozyskiwaniu i przetwarzaniu surowców naturalnych (KGHiM Polska Miedź S.A., International Paper S.A.). Pozycję monopolisty wskutek wyraźnej przewagi rynkowej osiągnęły więc przedsiębiorstwa, nad którymi kontrolę sprawuje państwo z uwagi na strategiczne znaczenie niektórych sektorów gospodarki (poszukiwanie, zagospodarowanie i dystrybucja złóż), a także przedsiębiorstwa, których właścicielami bądź udziałowcami są znani na całym świecie inwestorzy zagraniczni.

Obecnie, w dobie globalizacji, duże firmy coraz intensywniej dążą do pozyskiwania wpływów poza granicami własnego kraju. Celem ich ekspansji jest osiągnięcie dominującej pozycji na rynku światowym Przyjmuje się, że przedsiębiorstwa, których aktywa zlokalizowane są w co najmniej dwóch krajach, to przedsiębiorstwa (korporacje) międzynarodowe. Najbardziej rozpowszechnionym sposobem rozwoju korporacji międzynarodowych jest tworzenie oddziałów zagranicą poprzez lokalizację nowej fabryki w danym kraju lub poprzez wykupienie przedsiębiorstwa (posiadanie pakietu pozwalającego na kontrolę przedsiębiorstwem) już istniejącego na rynku lokalnym. Największe przedsiębiorstwa tworzą się przede wszystkim w krajach rozwiniętych gospodarczo. Wynika to z bardzo dużej chłonności ich rynków wewnętrznych, stabilności politycznej i społecznej, jak również ze względów technologicznych. Coraz chętniej koncerny międzynarodowe inwestują w krajach rozwijających się i słabo rozwiniętych. Motywem zainteresowania dużych firm tymi regionami jest dążenie do rozszerzenia rynków zbytu i obniżanie kosztów wytwarzania poprzez lokowanie pracochłonnych procesów wytwórczych w tych krajach (niskie koszty pracy). Nie mniej ważne dla inwestorów są liczne ulgi inwestycyjne, oferowane w krajach cierpiących 
na głód kapitału, czy łagodniejsze normy ochrony środowiska. Powstawanie filii firm międzynarodowych w krajach słabiej rozwiniętych jest zwykle dla tych krajów korzystne, gdyż napływ kapitału zagranicznego pozwala na transfer technologii oraz systemów organizacji i zarządzania, wzrost produkcji, szczególnie wyrobów nowoczesnych o wysokiej jakości, rozbudowę i unowocześnienie infrastruktury, ożywienie działalności gospodarczej, rozwój rynku pracy, podnoszenie kwalifikacji i dyscypliny zatrudnionych, aktywizację lokalnego biznesu, wzmożenie konkurencji, rozbudowę kontaktów zagranicznych lokalnych przedsiębiorstw, rozwój systemu informacji gospodarczej, ochronę środowiska naturalnego, wzrost eksportu. Korporacje kontrolujące rynek w wielu krajach uważane są za istotne, jeśli nie najważniejsze elementy budujące światowy system transferu środków kapitałowych.

Napływ inwestycji zagranicznych dokonuje się w formie inwestycji port-folio i bezpośrednich inwestycji zagranicznych (biz). Inwestycje port-folio to długoterminowe lokaty kapitału zagranica, kupowanie obligacji obcych rządów lub władz komunalnych, przejmowanie istniejących przedsiębiorstw drogą zakupu akcji lub wykupu w całości. Celem tych inwestycji jest otrzymanie wyższych odsetek lub dywidend niż w kraju macierzystym.

Znacznie trudniejsze jest zdefiniowanie zagranicznych inwestycji bezpośrednich. Niektórzy autorzy w swych definicjach przede wszystkim podkreślają ich międzynarodowy charakter i przeciwstawiają inwestycjom portfelowym. Inni wiążą je z działalnością firm międzynarodowych (i funkcjonujących na rynkach międzynarodowych). Większość definicji zawiera jednak dwa wspólne elementy: zagraniczne inwestycje bezpośrednie mają charakter międzynarodowy i związane są z własnością i zarządzaniem produkcją zagranica. Inwestycje bezpośrednie często związane są z przepływem czynników produkcyjnych, technologicznego know-how, wiedzy na temat organizacji i zarządzania. Do najpopularniejszych form biz w Polsce należą: współpraca $\mathrm{z}$ innym inwestorem (joint-ventures), fuzje i przejęcia (mergers \& acquisitions, M\&A), inwestycje od podstaw (greenfield).

Na ogół przyjmuje się, że bezpośrednie inwestycje zagraniczne to nabycie, ustanowienie lub zwiększenie możliwości produkcyjnych na zagranicznym rynku. W Polsce firmy zagraniczne lub z udziałem kapitału zagranicznego działają od 1976 r. Najpierw zwane były „polonijnymi”, z uwagi na początkowe priorytety dla zagranicznych rodaków, potem - zagranicznymi przedsiębiorstwami drobnej wytwórczości, bo do niej początkowo ograniczano udział obcego kapitału. Otwarcie polskiej gospodarki dla inwestorów zagranicznych przypada na lata 1986-1988. Okres ten charakteryzował rozwój tzw. joint ventures, które stanowiły spółki mieszane wyłącznie z przedsiębiorstwami państwowymi, w których udział zagraniczny nie mógł przekraczać 49\%. Dopiero ustawa o działalności gospodarczej z 23.12.1988 zapewniła prawo do $100 \%$ udziału zagranicznego, automatycznych wakacji podatkowych oraz częściowych zwolnień celnych. Podmioty zagraniczne musiały jednak w dalszym ciągu uzyskiwać zezwolenie na utworzenie spółki i obowiązywały je ograniczenia w transferze zysków. Pomimo liberalizacji handlu, spadku inflacji i urynkowienia gospodarki napływ kapitału zagranicznego na przełomie lat 80 . i 90 . był niewielki. Inwestorzy zagraniczni jeszcze nie w pełni ufali funkcjonowaniu mechanizmu rynkowego w Polsce, tym bardziej, że wskutek wdrożenia programu stabilizacyjnego nastąpił spadek popytu, a w rezultacie pogorszenie sytuacji finansowo-ekonomicznej przedsiębiorstw.

Napływ inwestycji zagranicznych do Polski (ryc. 1) wskazuje, że po zniesieniu barier, jakie istniały w Polsce przedkapitalistycznej, polski rynek stał się ważnym etapem ekspansji korporacji międzynarodowych. Do końca 2001 r. przeszło 800 dużych firm zagranicznych ulokowało po ponad 1 mld USD. W Polsce obecnych jest 70\% firm spośród 100 najwięk- 
szych korporacji międzynarodowych na świecie, m.in. France Telecom, Fiat, Nestlé, Thomson, Volkswagen, General Motors, International Paper, British Petroleum.

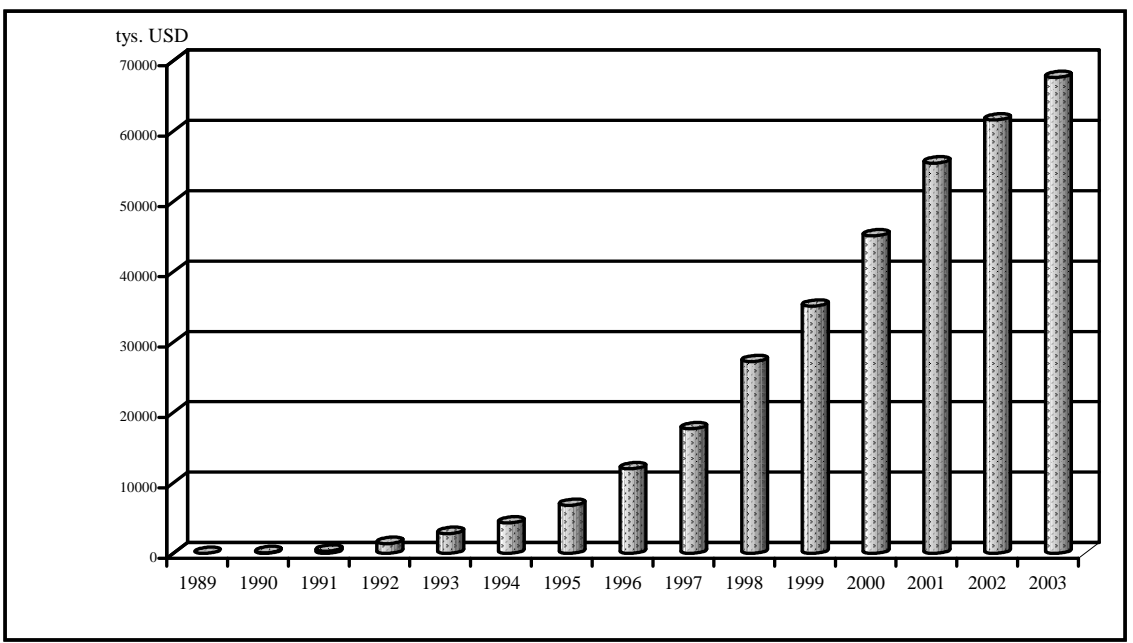

Ryc. 1. Skumulowana wartość biz w Polsce w latach 1989-2003 (w tys. USD) Źródło: PAIiIZ

$\mathrm{Z}$ punktu widzenia polskiej gospodarki koncerny zagraniczne mają istotne znaczenie dla podnoszenia poziomu konkurencyjności, gdyż poprawiają dostęp do rynków zbytu, wprowadzają nowe standardy, dokonują transferu technologii, wpływają na podnoszenie jakości produkowanych wyrobów i usług oraz poziom jakości kadr. Należy jednak pamiętać, że w Polsce znaczącą rolę w przyciąganiu inwestycji zagranicznych miała prywatyzacja, będąca dominującą formą fuzji i przejęć. Natomiast udział biz w projektach typu greenfield, będących najbardziej cenną formą bezpośrednich inwestycji zagranicznych, jest wyraźnie niewystarczający (w 1998 r. niespełna 1/4 inwestycji zagranicznych ulokowanych w przetwórstwo przemysłowe). Inwestycje tego typu są ważne z gospodarczego punktu widzenia, ponieważ tworzą najwięcej nowych miejsc pracy, w tym także w firmach lokalnych kooperantów (szacuje się, że jedno miejsce pracy powstałe w wyniku biz generuje średnio cztery nowe miejsca pracy w otoczeniu). Ponadto inwestycje od podstaw w największym stopniu wpływają na tempo podnoszenia konkurencyjności gospodarki, ponieważ generują wzmożony napływ nowoczesnych technologii oraz nowoczesnych metod zarządzania.

Obok wielkich firm w każdej gospodarce rynkowej działają małe i średnie przedsiębiorstwa (MSP), nazywane motorem wzrostu gospodarczego. W literaturze fachowej nie ma powszechnie stosowanej, opartej na naukowych kryteriach definicji małych i średnich przedsiębiorstw. W Polsce, podobnie jak w krajach UE, za małe przedsiębiorstwo uznaje się takie, które zatrudnia mniej niż 50 pracowników, osiąga roczny przychód netto ze sprzedaży towarów, wyrobów i usług oraz operacji finansowych poniżej $7 \mathrm{mln}$ euro lub sumę aktywów bilansu poniżej $5 \mathrm{mln}$ euro i spełnia kryterium niezależności, tj. przedsiębiorcy inni niż mali nie posiadają w tym przedsiębiorstwie powyżej $25 \%$ udziałów, wkładów lub akcji, ponad $25 \%$ prawa do udziału w zysku lub ponad $25 \%$ głosów w zgromadzeniu wspólników (akcjonariuszy). Natomiast za średnie przedsiębiorstwo uznaje się takie, które zatrudnia średniorocznie poniżej 250 pracowników, osiąga przychód netto ze sprzedaży towarów, wyrobów i usług oraz operacji finansowych nie przekraczający $40 \mathrm{mln}$ euro lub 
gdy suma aktywów jego bilansu sporządzonego na koniec poprzedniego roku obrotowego nie przekroczyła 27 mln euro i spełnia kryterium niezależności, tj. przedsiębiorcy inni niż mali lub średni nie posiadają w tym przedsiębiorstwie powyżej $25 \%$ udziałów, wkładów lub akcji, ponad $25 \%$ prawa do udziału w zysku lub ponad $25 \%$ głosów w zgromadzeniu wspólników (akcjonariuszy).

Drobna przedsiębiorczość* jest najczęściej spotykaną formą prowadzenia działalności gospodarczej, zarówno w krajach gospodarczo rozwiniętych, gdzie MSP stanowią uzupełnienie struktury przedsiębiorstw, jak i rozwijających się, gdzie niekiedy są podstawą gospodarki. Niezależnie od przyjętych kryteriów, przedsiębiorstwa małe i średnie posiadają przewagę liczebną wobec przedsiębiorstw dużych. W krajach Unii Europejskiej MSP stanowią 99,8\% ogólnej liczby przedsiębiorstw. Ich rozwój zapoczątkowany został w latach siedemdziesiątych. Wówczas w poszukiwaniu nowych dróg dynamizacji i utrwalania wzrostu gospodarczego zaczęto dostrzegać potencjał tkwiący w sektorze firm małych i średnich, które zapewniały coraz więcej miejsc pracy, jak też przyczyniały się do podnoszenia sprawności funkcjonowania gospodarki, głównie poprzez podejmowanie działalności w niszach rynkowych. Względnie mały rynek nie pozwala osiągać korzyści wynikających z produkcji na masową skalę, stąd sektor MSP zdominował produkcję dóbr i usług, w których konsument oczekuje indywidualnego wyrobu (np. stroje, biżuteria), usługi naprawcze, gdzie produkt nie jest standardowy i każda wykonana praca jest inna (np. remonty domów, naprawa samochodów, obuwia, zegarków), usługi osobiste, których wykonywanie związane jest z zaufaniem i wytwarzaniem się więzi emocjonalnych (np. fryzjer, kosmetyczka), małe rynki, których rozwój ograniczony jest czynnikami geograficznymi (np. społeczności małych wsi i miast nie są atrakcyjne dla supermarketów), rynki dóbr luksusowych, które ukierunkowane są na grupy społeczne o wysokich dochodach (np. jachty, samochody sportowe wysokiej klasy), produkcję wyspecjalizowanych dóbr wspomagających działalność dużych firm (np. montownie telewizorów, lodówek).

Zakładanie i rozwijanie drobnych i średnich przedsiębiorstw ma bezpośrednie znaczenie dla pobudzania i uruchamiania mechanizmów wzrostu gospodarczego. Działające w sferze gospodarczej małe firmy, w większości prywatne, aktywizują rozwój lokalny i regionalny. Charakteryzują się dużą elastycznością produkcji, relatywnie niskimi kosztami własnymi oraz racjonalną polityką płacową, powiązaną z rentownością i wydajnością pracy. Lepiej przystosowują się do zmieniających reguł gospodarowania niż duże. Wynika to z faktu, iż w podmiotach MSP stosuje się zazwyczaj uproszczone metody zarządzania, które umożliwiają szybszy przepływ informacji. Stosunkowo niewielkie rozmiary przedsiębiorstw pozwalają szybciej reagować na zmieniające się wymagania rynku i dostosowywać produkty do potrzeb, gustów i preferencji potencjalnych klientów. Ponadto charakteryzuje je niższa infrastrukturochłonność globalna. Firmy sektora MSP wykazują zwykle mały zakres negatywnego wpływu na środowisko, gdyż występują głównie w działach mało uciążliwych dla otoczenia. Ze względu na swój dynamizm i silny mechanizm motywacyjny MSP mają duże znaczenie dla sprawności i rozwoju gospodarki każdego kraju, gdyż tworząc lepsze warunki do stabilnej konkurencji rynkowej. Zazwyczaj małe i średnie firmy mają krótki żywot i na ogół pozostają niewielkimi przedsiębiorstwami, ponieważ ich właściciele nie dysponują dostatecznymi zasobami kapitału, umiejętnościami organizatorskimi i zarządczymi, pomysłami i dynamizmem, by stworzyć wielkie przedsiębiorstwo.

* Obok określenia MSP wobec sektora samodzielnych jednostek gospodarczych małych i średnich stosuje się inne, np. prywatna przedsiębiorczość, drobna przedsiębiorczość, small business, small and medium sized enterprise (SME), small and medium sized bisiness (SMB), kleine und mittelne Unternehmen (Mettelstand). 
W Polsce o sektorze MSP można w zasadzie mówić dopiero pod koniec lat osiemdziesiątych. Istotną rolę w procesie jego rozwoju odegrała ustawa z dnia 23.12.1988 o działalności gospodarczej, która gruntownie zmieniła podejście do indywidualnej działalności gospodarczej. Zakres monopolu państwa ograniczony został zasadą wolności gospodarczej, zakładającej swobodę podejmowania i prowadzenia działalności gospodarczej przez każdego, z zachowaniem warunków, które określają przepisy prawa. Ujednolicono zasady działania dla podmiotów publicznych i prywatnych w sferze finansowania (jednakowe zasady korzystania z kredytów bankowych), zaopatrywania się w środki produkcji, zniesiono ograniczenia w zatrudnieniu, ułatwiono rejestracje firm. W konsekwencji w latach 1991-1993 liczba małych i średnich przedsiębiorstw wzrosła pięciokrotnie. Główną przyczyną rozbudzenia przedsiębiorczości (eksplozji przedsiębiorczości) w tym czasie było rosnące zapotrzebowanie na wszelkiego rodzaju dobra, jako efekt długotrwałej przewagi popytu nad podażą towarów i usług. Zliberalizowane zasady tworzenia przedsiębiorstw przyczyniły się przede wszystkim do rozwoju handlu, który stwarzał możliwość szybkiego zarobienia pieniędzy przeznaczonych na szeroką konsumpcję. Wiele małych i średnich firm powstało również w wyniku podziału nieefektywnych dużych przedsiębiorstw państwowych oraz jako rezultat masowej prywatyzacji małych jednostek, np. sklepów, zakładów rzemieślniczych. W początkowym okresie funkcjonowania gospodarki rynkowej brak było inwestycji długookresowych, zwłaszcza o charakterze produkcyjnym, co nie rokowało szybkiego pokonania sytuacji kryzysowej. Ponadto ujawniły się liczne bariery rozwoju małych i średnich przedsiębiorstw w postaci braku odpowiednich zasobów kapitałowych, bariery lokalowe, administracyjne (biurokracja), systemu podatkowego i bankowego, a także brak zaplecza instytucjonalnego wspierającego ten sektor. Działania zmierzające do likwidacji barier i stworzenia dogodnych warunków (prawnych, podatkowych i finansowych) oraz rozszerzenia zinstytucjonalizowanej pomocy organizacyjnej, szkoleniowej i technicznej nastawionej na promocję przedsiębiorczości zostały podjęte przez rząd.

Aktywna rządowa polityka wspierania i rozwoju małych i średnich przedsiębiorstw, które przecież stanowią podstawę gospodarki opartej na konkurencji, została zadekretowana przez RM 6.06.1995. Efektem tych działań był rozwój prywatnych usług, w tym także w tak dotychczas silnie upaństwowionych dziedzinach gospodarki, jak: bankowość, turystyka zagraniczna i krajowa, budownictwo mieszkaniowe czy handel zagraniczny. Powstawać też zaczęły prywatne i społeczne szkoły podstawowe, średnie i wyższe, przedszkola, gabinety lekarskie oraz kliniki. Jednak tempo przyrostu małych i średnich przedsiębiorstw było znacznie niższe niż w pierwszym okresie transformacji. W latach 1995-1997 liczba podmiotów MSP zwiększyła się o 1/4. Począwszy od 1998 r. potencjał liczebny MSP ustabilizował się. Małe i średnie firmy stanowią około 99,8\% ogólnej liczby przedsiębiorstw w Polsce, podobnie jak w UE (tab. 2).

Tabela 2. Struktura wielkościowa przedsiębiorstw w Polsce i UE w \% w latach 1996 i 2000

\begin{tabular}{|l|r|r|r|r|}
\hline \multirow{2}{*}{ Przedsiębiorstwa } & \multicolumn{2}{|c|}{ Polska } & \multicolumn{2}{c|}{ Unia Europejska } \\
\cline { 2 - 5 } & 1996 & 2000 & 1996 & 2000 \\
\hline Małe & 98,87 & 98,98 & 99,00 & 98,97 \\
\hline Średnie & 0,88 & 0,81 & 0,80 & 0,83 \\
\hline Duże & 0,25 & 0,17 & 0,20 & 0,20 \\
\hline Razem & 100,00 & 100,00 & 100,00 & 100,00 \\
\hline
\end{tabular}

Źródło: opracowano na podstawie danych Polskiej Agencji Rozwoju Przedsiębiorczości i Eurostatu 
Jednakże sytuacja polskiego sektora MSP nie jest najlepsza. Słabością polskich małych i średnich firm jest ich rozbicie i niejednorodna struktura własnościowa. Tylko połowa sektora MSP należy do izb gospodarczych, podczas gdy w większości krajów UE przynależność do samorządu gospodarczego jest obligatoryjna. Ponadto w UE sektor MSP pozostaje w rękach prywatnych inwestorów, natomiast w Polsce prywatne są małe przedsiębiorstwa i tylko połowa $\mathrm{z}$ grupy przedsiębiorstw średnich. Z doświadczeń krajów rozwiniętych gospodarczo wynika, że sektor prywatny jest bardziej efektywny aniżeli przedsiębiorstwa publiczne. Ponadto polskie firmy wyraźnie odstają w stosunku do unijnych pod względem innowacyjności i wydajności. Jest to związanie z rozdrobnieniem firm - w UE przeciętna firma sektora MSP zatrudnia 6 osób, w Polsce 2 osoby. Wynika to z faktu, iż większość polskich MSP prosperuje w oparciu o samozatrudnienie przedsiębiorcy, który w często po prostu świadczy pracę, szukając w działalności gospodarczej sposobu na uniknięcie obciążeń nałożonych na pracę. Konsekwencją takiego stanu rzeczy są niewielkie nakłady na inwestycje. W 2002 r. niespełna 24\% wydatków wszystkich przedsiębiorstw na inwestycje pochodziło z sektora MSP, przy czym nakłady te były niższe o ok. $15 \%$ w stosunku do $2001 \mathrm{r}$. Jak wynika z raportu o stanie przedsiębiorczości w Polsce, opracowanego przez Ministerstwo Gospodarki, Pracy i Polityki Społecznej, nakłady inwestycyjne, zwłaszcza w małych przedsiębiorstwach, finansowane są w przeważającej części ze środków własnych. Główną przyczyną tej sytuacji są prawdopodobnie ograniczenia płynności dotykające najmniejsze firmy znacznie silniej niż większe, zjawisko to jest obserwowane we wszystkich gospodarkach rynkowych, łącznie z wysoko rozwiniętymi gospodarkami USA i UE. Drugim możliwym, choć prawdopodobnie mniej ważnym powodem tego stanu rzeczy jest stosunkowo niewielka skłonność małych przedsiębiorców do ryzyka. Właściciele mikroprzedsiębiorstw zazwyczaj najpierw gromadzą odpowiednie środki, a dopiero później inwestują, co powoduje, że jednorazowe wydatki na inwestycje ponoszone przez nich są relatywnie niewielkie. Pomimo że przedsiębiorcy dostrzegają zalety alternatywnych źródeł pozyskania środków finansowych: leasingu czy faktoringu, funduszy inwestycyjnych typu venture capital, funduszy pożyczkowych i poręczeniowych - nie są one w pełni wykorzystywane. Brak dostępu do źródeł finansowania jest najczęściej podawaną, obok kosztów finansowania działalności i złego ustawodawstwa, barierą hamującą rozwój przedsiębiorczości.

Podsumowując można stwierdzić, że jednym z bardziej widocznych skutków przekształceń systemowych w Polsce jest wzrost liczby przedsiębiorstw. Obok przedsiębiorstw gigantów, będących pozostałością gospodarki centralnie sterowanej, pojawiło się wiele nowych, zazwyczaj drobnych przedsięwzięć. Obecnie to właśnie małe i średnie firmy pełnią coraz ważniejszą rolę w polskiej gospodarce. W 2000 r. zatrudniały $67 \%$ ogółu pracujących $(7,4 \mathrm{mln}$ osób) i tworzyły blisko połowę polskiego PKB. Jednak w ostatnich latach ich rozwój został zahamowany. Pod koniec dekady lat dziewięćdziesiątych rosła co prawda liczba zarejestrowanych przedsiębiorstw małych i średnich, jednak zmniejszała się liczba firm aktywnych (tab. 3) i ich udział w ogólnej liczbie przedsiębiorstw MSP. W 1997 r. aktywną działalność prowadziło niemal 2/3 zarejestrowanych firm, natomiast w 2000 r. niespełna $55 \%$.

Można stwierdzić, że sektor, który w innych krajach, np. UE, jest wiodącym elementem gospodarki i motorem wzrostu gospodarczego, w Polsce przeżywa regres. Zachodzące wskutek transformacji gospodarczej przemiany ekonomiczne wymagają nowego podejścia do zagadnień efektywnego gospodarowania z ukierunkowaniem na rozwój przedsiębiorczości. Jest to szczególnie niekorzystne w kontekście problemu rosnącego bezrobocia i wchodzeniem w wiek produkcyjny kolejnych roczników wyżu demograficznego. 
Rola przedsiębiorstw w polskiej gospodarce w okresie...

Tabela 3. Zarejestrowane i aktywne przedsiębiorstwa sektora MSP w latach 1995-2000

\begin{tabular}{|c|c|c|c|c|}
\hline \multirow{2}{*}{ Rok } & \multirow{2}{*}{$\begin{array}{l}\text { Zarejestrowane } \\
\text { przedsiębiorstwa MSP }\end{array}$} & \multicolumn{3}{|c|}{ Aktywne przedsiębiorstwa MSP } \\
\cline { 3 - 5 } & 2093148 & Ogółem & $0-50$ & $51-250$ \\
\hline 1995 & 2373484 & 136808 & 1125656 & 11152 \\
\hline 1996 & 2546405 & 1580269 & 1328384 & 11885 \\
\hline 1997 & 2786462 & 1700616 & 1567413 & 12774 \\
\hline 1998 & 2845489 & 1689353 & 1675429 & 13322 \\
\hline 1999 & 3019592 & 1650428 & 1632884 & 13924 \\
\hline 2000 & & &
\end{tabular}

Źródło: opracowano na podstawie danych Polskiej Agencji Rozwoju Przedsiębiorczości, GUS i Eurostatu

\section{Literatura}

Bąk M. i in., 2001, Mate i średnie przedsiębiorstwa a rozwój regionalny, PARP, Warszawa

Chojka J. (red.), 2002, Rola matych i średnich przedsiębiorstw $w$ rozwoju regionalnym, WSE, Warszawa

Domański B., 2001, Kapitał zagraniczny w przemyśle Polski, UJ, Kraków

Lewandowski M., 2001, Fuzje i przejęcia w Polsce na tle tendencji światowych, Warszawa

Przedsiębiorczość w Polsce. Raport, 2003, Ministerstwo Gospodarki, Pracy i Polityki Społecznej, Warszawa

Tokarski A., Tokarski M., 2002, Szanse i zagrożenia polskiego sektora matych i średnich przedsiębiorstw w perspektywie integracji Polski z Unia Europejska, „Firma i Rynek”, nr 3

Ważniewski P., 2003, Sektor matych i średnich przedsiębiorstw w Polsce i Unii Europejskiej, „Gospodarka Narodowa", nr 5-6

Zorska A., 1998, Ku globalizacji? Przemiany $w$ korporacjach transnarodowych $i$ w gospodarce światowej, PWN, Warszawa 